DOI 10.18551/rjoas.2019-09.20

\title{
CORPORATE'S LEGAL RESPONSIBILITY TOWARDS FOREST DAMAGE IN RIAU PROVINCE OF INDONESIA
}

\author{
Fahmi $^{*}$, Associate Professor \\ Triana Yeni, Lecturer \\ Faculty of Law, University of Lancang Kuning, Indonesia \\ *E-mail: fahmihukum123@gmail.com
}

\begin{abstract}
The corporate responsibility issues concerning forest damage in Riau province still raise debate that has lasted for so long that causes societies' unrest to it. Following the public space towards company's responsibility, the government and society are able to coordinate in maintaining the law. The objective of this research is to identify the corporate's legal responsibilities towards forest damage in Riau Province. The research method was sociological legal research which more focuses on the problems which arise. So, the researcher focuses the discussion on how the law is practiced by the societies. The result indicates that corporate's legal liability towards damage in Riau Province has not been asked maximum legal liability. There should be coordination and cooperation with relevant institutions to establish the law smoothly without any obstacle. The conclusion of research is to maximize the coordination steps towards relevant institution by asking for various parties' responsibilities so forest damages such as forest and land fire in Riau Province do not occur anymore.
\end{abstract}

\section{KEY WORDS}

Responsibility, company, forest, public space.

Living environmental issues have become many parties' attention on local, national or international scale which emerges as a response towards the rate of faster environmental quality and quantity degradation as the world population growth. Living environmental issues have become chronical disease which can't be easily healed. Whereas, they occurred in Indonesia as the impact of development paradigm which prioritizes economics growth and ignores environmental factors.

Corporation as an entity or legal subject which existence provide big contribution in the economics growth and national development. However, in fact, sometimes corporations do corporate crimes that bring a loss towards the environment.

Based on Article 74 Paragraph (1) Act Number 40 Year 2007 on Limited Corporations, it was stated that Limited Corporations which run their business in and /or related to natural resource must maintain corporate social responsibilities. Most of pollution or environmental damages are related to business run and businessmen's behavior that ignore their responsibilities of living environmental management. Therefore, in this case corporation must take the responsibilities. Based on Article 87 Act Number 32 Year 2009 on Protection and Management of Living Environment, the business person in charge and/or activities which cause living environment damage must pay the compensation and/or perform certain actions. Therefore, corporate responsibilities in living environment borne by the head of corporation and their management (director, managers who are responsible for the company's living environment management, or even stakeholders and commissaries) who collectively perform activities or corporation business that damage living environment.

Forest and land fire issues in Riau will become routine problems if the government, businessmen, and societies do not immediately follow up and take action by minimizing the impacts of forest fires in Riau and other regions because the increasing environmental crisis and land disputes which end with bad precedents that threaten environment and human existence. One of basic issues is the weak legal contribution which cause low environmental 
management level. Not only institutional or coordination empowerment among the institutions but also rule of the game that can manage all environmental issues must be done.

The problem formulations are:

- What are the Corporate Responsibilities towards Forest Damage in Riau Province?

- What are the Corporate Responsibility obstacles towards Forest Damage in Riau Province?

- What are the Corporate Responsibility Efforts towards Forest Damage in Riau Province?

\section{LITERATURE REVIEW}

Previous researches on Corporate Responsibilities in Riau Province were performed by some researchers. However, the present research is different from the previous research such as: Ridwan Rangkuti's research which is entitled "Corporate Responsibilities towards living environment criminal actions according to Act Number 23 Year 1997". In his research, he found out the corporate responsibilities which became indicators so that corporation's head must take the criminal and civil responsibilities towards the living environment pollution and damage according to Act Number 23 Year 1997.

Based on the result, the management of corporate responsibilities and indicators of corporate's head who can bear the responsibilities and the forms of responsibilities have been adequately managed in Act Number 23 Year 1997 that stated any corporate's head who runs his business but cause living environment damage and/or pollution will be sentenced for a crime plus fine compensation according to civil law.

Erdiansyah's research which is entitled "The Corporate's Criminal liabilities of forest and land fires in Riau Province. In the development of Indonesian criminal law systems, corporations bear criminal liabilities or can be said as the criminal law subjects. Based on the implementation of Corporate's Criminal Responsibilities of Forest and Land fire in Riau Province, although forest and environment act can be the law foundation to bear criminal liability towards corporation, until present Criminal Courts are reluctant to acknowledge and use the rules. The obstacles of Corporate's Criminal Liability Implementation of Forest and Land Fire in Riau Province are: (a) The unsimplicity of legal and regulation entity; (b) Professionalism of environmental law enforcer apparatus, and; (c) The societies' legal awareness and facilities which support the law enforcement.

\section{METHODS OF RESEARCH}

Sociological legal research was intended to find out the social symptoms which occurred in the societies and were related to the statutory provisions.

This research was conducted at Police Area of Riau Province. The selection reason was because the forest fire in Indonesia cannot be separated from the patterns of bad land and forest use policy in this country. Routine forest fire for a decade was merely caused by ecological chain change.

Table 1 - Population and Sample Numbers

\begin{tabular}{|c|l|c|c|c|}
\hline No & Sub Population & Population & Sample & Percentage (\%) \\
\hline 1 & Ditreskrimum Polda Riau & 15 & 5 & $75 \%$ \\
\hline 2 & Investigator Ditrreskrimum Regional Police Riau & 60 & 10 & $6 \%$ \\
\hline 3 & Forest Fire Perpetrators & 10 & 5 & $5 \%$ \\
\hline 4 & Investigator of Forest Department & 15 & 3 & $45 \%$ \\
\hline 5 & Corporations assumed to do forest fire. & 10 & 5 & $5 \%$ \\
\hline \multicolumn{2}{|c|}{ Total } & 110 & 28 & \\
\hline
\end{tabular}

The respondent selection utilized Purposive Sampling, which was a research that utilized own considerations with sufficient knowledge on population to select the sample members. The research data was obtained from respondents, the researcher utilized 
purposive method, taking data from population which represented the determined sample category. Purposive method was utilized because the populations were heterogeneous and it provided easiness for the author to find and collected the data from respondents. Besides, it also utilized census method.

Data which is utilized in the field directly as the issues discussed as the respondents which were determined by the author. Data obtained from decision literatures which supported the primary data. It was obtained from supporting primary data in which it was related to the research. Data obtained from dictionary and other types of dictionary which had function to support primary and secondary data.

\section{RESULTS AND DISCUSSION}

The term "punishment" is a general and conventional term which has wide and changing mining because it can be connoted with wide field. The term is not only utilized in law field but also daily terms in education, moral, religion etc.

Forest fire in Indonesia has lasted for long. It was noted from the smoke which was spread in Riau in 1997. At that time, the societies who were accustomed to live in clean air quality were disturbed by the smoke could damage the health. Schools were off and the societies used mask to breathe. Many smoke victims were brought to the hospital because of ISFA (Upper Respiratory Tract Infection). Also, long term loss which affect the health if they inhale unhealthy air. Besides, the forest ecosystem is disturbed. Many animals lost their place because they were burnt. Even, wild animals can enter the residential area because they lost their place. Plantation is also dead because of the fire. So it increase the animal and plant scarcity level. The inharmony is replaced with palm oil plantation which only be beneficial for some parties. This unhealthy air lasts for more than a month and occurs annually.

Many questions on who will take the responsibilities arise. First, parties who must be responsible are people who have business on the land and them who cause the fire because they are paid by their employer. Besides, the societies are also responsible because they use land burning method during the summertime (interview result with Director of PT.NSP). If it is done on small land, the effect will be small, and vice versa. Second, law enforcer are considered as slow to catch the culprits. Third, punishment. Can the punishment give deterrent effect towards the parties who take the responsibilities? Fourth, the relevant corporations that have interest on the land. In this case, parties who have authority only catch the culprits. Only a small part of corporation which bear the responsibility. The law enforcer apparatus have difficulty to catch the director.

Based on the interview result with Mr. AKBPBEddy Faryadi, SH., M.H the vice director of Rekrimsus Regional Police Riau, "Regional Police Riau performs Socialization Activity as the Effort to prevent forest and land fire which often occur every year in Riau Province. So, Regional Police Riau performs the socialization to societies and stakeholders by providing the materials on the understanding and knowledge, and information on the prohibition of land and forest fire. Regional Police of Riau issues Regional Police Chief Notice of Riau (Kapolda Riau) Number; Mak/1/VI/2013 on Forest and Land Fire Prevention and Fire Suppression and Number: Mak/1/II/2014 on Forest and Land Fire Prohibition as the preventive action".

Living environment pollution and/or damage is increasing as the industrial development. Certainly, it should get legal protection. Living environment with its resource is collective wealthy which can be used by every individual that must be maintained for the societies' interest and future generation. The living environment and natural resource protection have multiple objectives, such as to serve the societies and individuals' interest.

Forest fire in Indonesia cannot be separated from the bad patterns of land and forest use policy in this country (interview result with Director of PT.SRL). Forest routine fire for this decade is not merely caused by the ecological chain change. However, it is influenced by intentional element of big-scaled-plantation businessmen in opening the land. Besides, it is also the industrial businessmen' ignorance and the uncontrolled permit issue process of area authority. It indicates that the monitoring and prevention of forest and land fire in Riau is low. 
Based on the interview result with Kombes Hadi Poerwanto, $\mathrm{SH}$, SIK as the Distreskrimun of Regional Police Riau on the Corporate's Responsibilities towards forest damage in Riau Province, he stated that:

Not only the fire culprits, but also the corporation that must be the most responsible party towards the land fire. Even, the culprits are not the corporation employees. It seems difficult to achieve. The societies should keep the environment well. The act should be more assertive to punish the criminal actors. The law apparatus are expected to be able to investigate the responsible parties fully so they can get equal punishment. The weak enforcement becomes one of obstacles in handling the forest fire.

The obstacles faced by Criminal Investigation Agency of Regional Police Rio in the Law Enforcement towards Corporate's Responsibly on Forest Damage are:

Internal Factors:

- Infrastructure and facility obstacles in the observation and investigation process towards the law enforcement of forest and land fire case handled by Ditreskrimsus Regional Police Riau, especially Subdit IV, is the infrastructure and facility obstacles. It is seen from the inexistence of living environment laboratory facility in Regional Police Riau and lack of car transportation facility;

- Financial obstacle especially in the forest and land fire case handling has not been established. The forest and land fire case handling in the observation and investigation process need approximately Rp 25, 000, 000,- (twenty five million rupiahs) each case. While the total budget owned by Ditreskrimsus Regional Riau is Rp 273.500.000,- (two hundred seventy three and five hundred thousand rupiah) in which the total is used by four Subdits in the Ditreskrimsus Regional Police Riau;

- Human Resource Obstacle is related to quantity and quality aspects of legal enforcer aspects. In the quantity, the numbers of investigators and investigator assistants are only 20 (twenty) people. In the quality, the investigation members Subdit IV Ditreskrimsus Polda Riau have never joined living environmental investigation training. Therefore, the lack of investigation members' quantity and quality will cause the less maximum law enforcement process.

External Factors:

- Societies' obstacles in handling the forest and land fire case which almost occurs annually in Riau Province. They are important because the lack of societies' legal awareness and their economics condition (Interview result with Aron Purba, SH., MH Forest Department Investigator);

- Far Crime Scene Location. So the law enforcement performed by the investigator of Distreskrimsus Regional Police Riau, especially Subdit IV cannot run maximally because the transportation facilities are not available well. Whereas, they are demanded to be fast and responsive towards the report on criminal action concerning forest and land fire so that the actors can be caught immediately and processed under the law;

- The obstacle of inviting Environmental Experts. The required experts are land damage, forest fire, peat, and environment legal experts. However, the limited numbers of experts accompanying the high business level, the investigation process is hampered.

\section{CONCLUSION}

The Corporate Responsibility Enforcement towards forest damage has not been done maximally. They need coordination from various relevant institutions such as Forest Department of Riau Province, Living Environment Agency of Riau Province, and sometimes to invite experts from Bogor Agricultural Institute.

The obstacles which are faced in law enforcement towards the corporate's responsibilities according to Criminal Investigation Agency of Regional Police Riau towards forest damage actors, lack of socialization of forest and land fire law enforcement. Then it causes the hampered enforcement towards the fire actors which until presents are hard to 
know. In order to prove it, the court still faces legal issues because they find difficulty to find the evidences based on the law and decide who will take the responsibility towards the criminal acts performed by the corporation. As a result, the corporates' liability of forest and land fire in Riau Province has not been maximized.

The efforts which are performed by Criminal Investigation Agency of Regional Police Riau to solve the obstacle in environment criminal law enforcement towards the forest and land fire actors are by maximizing the internal and external actors possessed by Regional Police of Riau especially Ditreskrimum Regional Police Riau such as by giving coaching, training and education to their members and personnel, coordinating with relevant institutions for the law enforcement of land and field fire actors.

\section{RECOMMENDATIONS}

To Regional Police Riau, especially Ditreskrimum Regional Police Riau in order to implement environment criminal law enforcement, it is expected to be consistent and improve the weakness and functions as legal apparatus both it is preventive and repressive. Therefore, the law enforcement steps towards forest and land fire actors can be handled maximally.

To Regional Police Riau, especially Ditreskrimum Regional Police Riau in order to overcome the environment criminal law enforcement caused by internal and external factors, it is expected to improve work professionalism and quality of members or investigator personnel especially in living environmental field. So the problem can be overcame maximally.

To Regional Police Riau, especially Ditreskrimum Regional Police Riau in order to improve preventive stages through socialization to the societies or businessmen in plantation sector. Besides, good coordination steps performed by Ditreskrimum Regional Police Riau, relevant institutions and stakeholders are expected to provide maximum effort to prevent and enforce the law. In the future, it is expected that the forest and land fire will not occur anymore in Riau Province.

\section{REFERENCES}

1. Adhy Prayitno, 2014, Pengendalian and Pencegahan Karhutla Gambut dari Perspektif Teknik Kendali dalam Ashaluddin Jalil, Haris Gunawan, and Arifudin (editor), Jerebu di Negeri Kami, Universitas Riau Press, Pekanbaru.

2. Arifudin, 2014, Menyoal Sosial Ekonomi Masyarakat Pada Kawasan Kebakaran Lahan Gambut dalam Ashaluddin Jalil, Haris Gunawan, and Arifudin (editor), Jerebu di Negeri Kami, Universitas Riau Press, Pekanbaru.

3. Andi Hamzah, 2005, Kriminologi and bentuk Kejahatan, Raja Grafindo, Jakarta.

4. Asri Muhammad Saleh, 2003, Menegakkan Hukum atau Mendirikan Hukum, Bina Mandiri Press, Pekanbaru.

5. Bagir Manan, 2009, Menegakkan Hukum Suatu Pengantar, Asosiasi Advokat Indonesia, Jakarta.

6. Baharudin, 2000, Tindak Pidana and Kriminologis, Citra Aditya Bakti, Bandung.

7. Hikmahanto Juana, 2002, Bunga Rampai Hukum Ekonomi and Hukum Internasional, Lentera Hati, Jakarta.

8. Jurnal Widia Edorita, 2011, Pertanggung Jawaban Terhadap Pencemaran and Perusakan Lingkungan Hidup Akibat Kebakaran Hutan Dilihat Dari Perspektif Hukum, Artikel Pada Jurnal IImu Hukum, Fakultas Hukum Universitas Riau, Vol II, No. 1 Februari.

9. Lembaran Negara Republik Indonesia Tahun 1981 Nomor 76.

10. Lembaran Negara Republik Indonesia Tahun 2002 Nomor 2.

11. Lembaran Negara Republik Indonesia Tahun 2009 Nomor 140.

12. Peraturan Perundang-Undangan Kitab Undang-Undang Hukum Acara Pidana Nomor 8 Tahun 1981. 
13. Rahmadi, Takdir, 2012, Hukum Lingkungan di Indonesia, PT Raja Grafindo Persada, Jakarta.

14. Santosa, Mas Achmad, 2001, Good Governance Hukum Lingkungan, ICEL, Jakarta.

15. Soekanto, Soerjono, 2005, Faktor-Faktor Yang Mempengaruhi Penegakan Hukum, PT Raja Grafindo, Jakarta.

16. Suparni, Niniek, 1992, Pelestarian, Pengelolaan and Penegakan Hukum Lingkungan, Sinar Grafika, Jakarta.

17. Satjipto Rajarjo, 1997, Permasalahan Hukum di Indonesia, Alumni, Bandung.

18. Tambahan Lembaran Negara Nomor Undang-Undang Nomor 2 Tahun 2002 tentang Kepolisian Negara Republik Indonesia.

19. Tambahan Lembaran Negara Nomor Undang-Undang Nomor 32 Tahun 2009 tentang Perlindungan and Pengelolahan Lingkungan HiduP.

20. Tambahan Lembaran Negara Nomor Peraturan Kepala Kepolisian Negara Republik Indonesia Nomor 22 Tahun 2010 tentang Susunan Organisasi and Tata Kerja Pada Tingkat Kepolisian Daerah.

21. Lembaran Negara Republik Indonesia Tahun 2010 Nomor 477.

22. http://docplayer.info/43869484-Penegakan-hukum-pidana-lingkungan-oleh-direktoratreserse-kriminal-khusus-kepolisian-daerah-riau-terhadap-pelaku-pembakaran-hutan-danlahan-oleh.html 